\title{
Hastanelerde Tesis Güvenliği ve Önemi
}

\author{
Facility Safety and Importance in Hospitals
}

\section{Mustafa METE* iD, Berna KAHVECI CEYLAN**iD, Gülsüm Serap TATLIOĞLU***iD}

\begin{abstract}
ÖZET
Hastaneler sağlık konusunda rahatsızlı̆̆ı bulunan tüm insanlara hizmet vermektedir. Bunun yanında să̆lıkla ilgili araşstırma, eğitim ve danışma gibi önemli hizmetleri de yerine getirmek zorundadır. Birer sağllk tesisi olan hastaneler, yoğun bir şekilde ileri teknolojiyi kullandıkları için bazı olası risklerle karşı karşıyadırlar. Bu risklerin olmaması veya en düşük düzeyde olması yönetici, çalışan, hasta ve hasta yakını açısından da büyük önem arz eder.

İşletme güvenliğini sağlayabilmek için yöneticiler, bir sağlık tesisinde, risklerin azaltılıp kontrol altına alınması, kazaların önlenmesi, güvenli bir tedavi ortamının sağlanması için gerekli tedbirleri ve önlemleri almak ve aldırmak zorundadırlar. Ayrıca hastane hizmetlerinde cihaz arızaları nedeniyle oluşan kesintiler ve gecikmeler halkın o kuruma olan güveni üzerine negatif etkiler yaratabilir.

Bu konuda Să̆lık Bakanlı̆̆ınca çıkartılan mevzuat dahilinde gerekli çalışmaları yapmak, planları oluşturmak ve gerekli tatbikatları yaparak afetler ve acil durumlar karşısında hazırlıklı olmak yönetimlerin öncelikli görevleri arasında yer almaktadir.

Çă̆daş ve modern bir toplum olmanın ana şartlarından biri afetlerde ve acil durumlarda zarar görenlerin mağduriyetini gidermek, yaralarını kısa zamanda sarmak ve sosyal hayata tekrar kavuşmalarına yardımcı olmaktır. Bu konuda alınacak tedbirler, afetlerde hastanelerin işlev kaybını önleyecek ve daha düzgün hizmet vermesini temin edecektir.
\end{abstract}

Anahtar Kelimeler: Hastane, afet, risk, tehlike, güvenlik

\begin{abstract}
Hospitals serve all people with health problems. It also has to carry out important services such as health-related research, education and counselling. Hospitals with health facilities face some potential risks as they use advanced technology extensively. The absence or the lowest level of these risks is of great importance for the manager, employee, patient and patient relatives.

In order to ensure operational safety, managers must take and have the necessary measures and measures taken in a health facility to reduce and control risks, prevent accidents, and provide a safe treatment environment.

In addition, interruptions and delays due to device failures in hospital services have negative effects on public trust in the institution. It is among the priorities of the administrations to carry out the necessary studies, to prepare the plans and to prepare for the disasters and emergencies in the legislation issued by the Ministry of Health.

One of the main conditions of being a modern and modern society is to eliminate the victims of disasters and emergencies, to shorten their wounds and to help them regain their social life. Measures to be taken in this regard will prevent the loss of function of hospitals in disasters and ensure that they serve more properly.
\end{abstract}

Keywords: Hospital, disaster, risk, danger, security

Geliş Tarihi / Received: 18.05 .2020

Kabul Tarihi / Accepted: 02.07.2020

* Dr. Öğr. Üyesi, İstanbul Aydın Üniversitesi Anadolu Bil Meslek Yüksekokulu, Sağlık Kurumları İşletmeciliği Programı ** Öğr. Gör., İstanbul Aydın Üniversitesi Anadolu Bil Meslek Yüksekokulu, Sağlık Kurumları İşletmeciliği Programı *** Öğr. Gör., İstanbul Avrupa Meslek Yüksek Okulu

Sorumlu Yazar / Corresponding Author: Mustafa METE, mustafamete@aydin.edu.tr 


\section{GİRIŞ}

Hastaneler hasta ve yaralılara tedavi edici hizmetler sunmaktadır. Hastaneler tedavi edici hizmetlerinin yanı sıra ayrıca sağlıkla ilgili araştırma, eğitim ve danışma gibi önemli hizmetleri de yerine getirmekte ve yürütmektedirler. Hastaneler bu hizmetleri yerine getirirken ve yürütürken yoğun bir şekilde teknolojiyi kullanır. Teknolojinin yoğun bir şekilde kullanılması bazı olası riskleri de beraberinde getirmektedir. Güvenli ortam (çevre) kısaca, bireyin yaşam aktivitelerini sağlıklı biçimde yerine getirdiği ve güven duygusu hissettiği ortam olarak tanımlanabilir. Güvenli ortam birey, toplum ve gelecek nesillerin sağlıkları için hayati önem taşımaktadır (Sur, Çetin, 2002).

Tesis kelimesini, tanı ve tedavi hizmetinin sunulduğu bina ve tamamlayıcı üniteler olarak tanımlamak mümkündür. Güvenlik kelimesi de çalışanlar ve müşteriler başta olmak üzere bir kuruluşun tam ve mevcut paydaşlarının "kazayla yaralanmaya maruz kalmamaları" olarak ifade edilebilir.

Tesis Güvenliğini ise, hastalar, hasta refakatçileri, hasta yakınları, ziyaretçiler ve çalışanlar için güvenli ve işlevsel sağlık tesisinin oluşturulması ve bunun devam ettirilmesi olarak ifade etmek yerinde olur. Bir sağlik tesisinde;

- Tehlike ve risklerin azaltılıp kontrol altına alınması,

- Kazaların ve yaralanmaların önlenmesi,

- Emniyet koşullarının sağlanması için etkin bir yönetim oluşturulmasıdır.

Joint Commission International (JCI); sağlık hizmetlerinin kalitesini ve güvenliğini artırmaya odaklanmış, kâr amacı gütmeyen Joint Commission on Accreditation of Healthcare Organizations (JCAHO) kurumunun, uluslararası akreditasyon hizmetleri için oluşturulmuş birimidir.

Sağlık Kuruluşuna getirdiği Efektiftik ve Standartlaşmanın yanı sıra kurum dışında da Saygınlığın ve Prestijin bir ölçüsü olarak kullanılan JCI akreditasyon standardı Organizasyon ve Hasta Odaklı standartlar olarak iki temel gruba ayrılmaktadır. Sağlıkta akreditasyon kriterleri olarak tanımlanan ve Türkçeye de çevrilen standardın 2003 yılı versiyonu şu başlıklardan oluşmaktadır;

Tablo 1. Hasta Odaklı ve Organizasyon Odaklı Standartlar

\begin{tabular}{|l|l|}
\hline HASTA ODAKLI & ORGANIZASYON ODAKLI \\
\hline Hizmete erişim ve hizmetin sürekliliği & Kalite iyileştirme ve hasta güvenliği \\
\hline Hasta ve yakınlarının hakları & Enfeksiyonların önlenmesi ve kontrolü \\
\hline Hastaların değerlendirilmesi & Yönetişim, liderlik ve yönlendirme \\
\hline Hastaların bakımı & Tesis yönetimi ve güvenliği \\
\hline Hasta ve yakınlarının eğitimi & Çalışanların niteliği ve eğitimi \\
\hline Anestezi ve cerrahi bakım & İletişim ve bilgi yönetimi \\
\hline İlaç yönetimi ve kullanımı & \multicolumn{2}{|l}{} \\
\hline
\end{tabular}

Kaynak: Joint Commission International Standartları (2014) 
Joint Commission International Standartlarında Tesis Güvenliği bölümü 27 Standart Maddesinden 13 Temel 78 ölçülebilir element için Sağlık Bakanlığınca 06 Ağustos 2013 tarihli 28730 sayılı Resmî Gazetede "Sağlık Hizmeti Kalitesinin Geliştirilmesi ve Değerlendirilmesine Dair Yönetmelik" yayınlanmıştır. $\mathrm{Bu}$ yönetmelikle sağlık kurum ve kuruluşlarında kaliteli hizmet sunumunun sağlanması amacıyla, hasta güvenliği, çalışan güvenliği, hasta memnuniyeti ve çalışan memnuniyetini esas alan Sağlık Hizmet Kalite Standartları Hastane (SHKS, 2016) ile bu standartların uygulanmasına ilişkin usul ve esasları düzenlenmiştir. Ayrıca bu konuda "Sağlık Bakanlığına Bağlı Sağlık Kurum ve Kuruluşlarında Kaliteyi Geliştirme ve Performans Değerlendirme Yönergesi” 23.03.2007 tarih ve 2542 sayılı Makam Onayı ile yürürlüğe girmiştir.

Diğer taraftan, hastaneler karmaşık organizasyonlar olup, benzer büyüklükteki diğer organizasyonların en karmaşık olanlarındandır. Çalışan meslek gruplarının fazla oluşu, nitelikleri yüksek birçok meslek grubunun bir arada bulunması ve buna ilaveten tesiste kullanılan altyapı ve tıbbi cihazların çeşit ve sayıca artışı, bu faktörlerle insan sağlığına hatasız hizmet sunması için organizasyonlar yapılma zorunluluğu, hastaneleri daha da karmaşık hale getirmiştir (Odacığlu, 2013:179-185).

\section{GÜVENLİ HASTANE}

Türkiye sahip olduğu coğrafi ve jeolojik yapı nedeniyle doğal afet olayları ile sikça karşılaşmaktadır. Doğal afet olarak özellikle de deprem ülkemizin başta gelen bir gerçeğidir. Hastane yapıları, Resmî Gazetenin 06.03.2007 tarih ve 26454 sayılı nüshasında yayınlanan "Deprem Bölgelerinde Yapılacak Binalar Hakkındaki Yönetmelik”, ve TS500 ve TS498 ve ilgili diğer şartnameler dikkate alınarak projelendirilir, uygulama sırasında da projeye uygunluğu kontrol edilerek deprem dayanıklılığı ve güvenliği sağlanmaktadır (Demircioğlu, 2010).

Hastaneler aynı zamanda tıbbi cihaz teknolojileri ve bunların güvenliği konusunda zorunlu olarak alt yapıya da sahip olmalıdırlar. Hastane hizmetlerinde cihaz arızaları nedeniyle oluşan kesintiler, halkın o kuruma olan güveni üzerine kalıcı negatif etkiler yaratabilir.

\section{"Güvenli Hastane" Kavramı:}

- Afet hali (deprem, firtına, sel, savaş, vs.);

- Yangın, enfeksiyon, radyasyon, çevre kirliliği;

- Hırsızlık, kaçakçılık, vs. gibi her ölçek ve türde fiziksel, kimyasal ya da psikolojik saldırı, tehlike ya da zararlara karşı azami önlem ve düzenlemeleri içeren;

- Sağlıklı bir atmosfer üreten ve hoşa gitmeyen ya da zarar verici koku, ses, görüntü, temas vb. duygusal ve fiziksel etkilerin ortadan kaldırıldığı;

- Kullanıcı tüm bireyler için rahatlatıcı ve sağlıklı bir atmosfer üreten hastane ortamını ifade eder. 


\section{Güvenli Hastaneler İçin Yapılması Gerekenler şunlar olabilir; (Şengöz,} https://buraksengoz.wordpress.com/2016/04/21/2/ 20.02.2020)

1. Güvenli hastaneler için ulusal bir politika ve program kabul edilmelidir.

2. Esnek hastane tasarım ve inşası esas alınmalıdır.

3. Hastanenin güvenliğinin değerlendirilmesi gereklidir.

4. Acil müdahale için planların hazırlanması zorunludur.

5. Acil durumlar için sağlık çalışanları eğitimi tamamlanmış olmalıdır.

6. Ekipman, ilaç ve malzemelerin korunması konusunda gerekenler yapılmalıdır.

Güvenli hastanelerin sağladığı yararlar şöyle sıralanabilir (Özmen, vd, 2013);

1. Sağlık tesislerinin yapısal dayanıklılığını sağlayarak hastaların ve sağlık çalışanlarının hayatını korur.

2. En çok ihtiyaç duyulan zamanda sağlık hizmetlerini acil ve afet sonrasında mümkün olduğunca işler tutar.

3. Sağlık çalışanları ve kurumlarının acil durum yönetim kapasitesinin geliştirilmesini ve riskin azaltılmasını sağlar.

\section{“Güvenli Hastane” Tasarım Süreci}

- Hastane yapım kararı alınması, ön fizibilite çalışmasının yapılması,

- Kentsel ya da bölgesel planlamanın yapılması

- İhtiyaç çerçevesinde, hastane özellik ve büyüklügünün tespiti,

- Arsanın seçimi, zemin durumunun belirlenmesi,

- Tüm disiplinlerde (mimari, mekanik-tesisat, elektrik, statik, yangın, vs.) projelendirme yap1lmas1.

Tablo 2. Güvenli Hastane Tasarım Süreci

\begin{tabular}{|l|}
\hline 1-Hastane yapım kararı alınması, ön fizibilite çalışmasının yapılması \\
\hline 2-Kentsel ya da bölgesel planlamanın yapılması, \\
\hline 3-İhtiyaç çerçevesinde, hastane özellik ve büyüklüğ̈unün tespiti, \\
\hline 4-Arsanın seçimi, zemin durumunun belirlenmesi, \\
\hline $\begin{array}{l}\text { 5-Tüm disiplinlerde projelendirme yapılması, (Mimarı, mekanik, tesisat, } \\
\text { elektrik, statik, yangın vs.) }\end{array}$ \\
\hline 6-Uygulama ve yapım süreci \\
Kaynak: Demircioğlu, 2010
\end{tabular}




\section{Buna göre Güvenli Hastane unsurlarını şöyle sıralamak mümkündür:}

1. Yapısal unsurlar: (Mühendislik, kolon, kiriş vs.)

2. Yapisal olmayan unsurlar:(Raf, mekanik ekipman, vs.)

3. Fonksiyonel unsurlar: (Politikalar, eğitimler.)

Sağlık kuruluşlarında ve özellikle hastanelerde aşağıdaki hususların çok iyi takip edilmesi önem arz etmektedir.

- Tehlikeli maddelerin yönetimi,

- Acil durum yönetimi,

- Yangın risk değerlendirmesi ve yangın emniyetinin sağlanması,

- Tıbbi ekipmanların kontrolünün sağlanması,

- Gaz-su-elektrik sistemlerinin gözden geçirilmesi,

- Personelin tesis yönetimi ve güvenlik konusunda eğitim ve donanımının sağlanması,

- Emniyet ve güvenlik kontrolünün sağlanması.

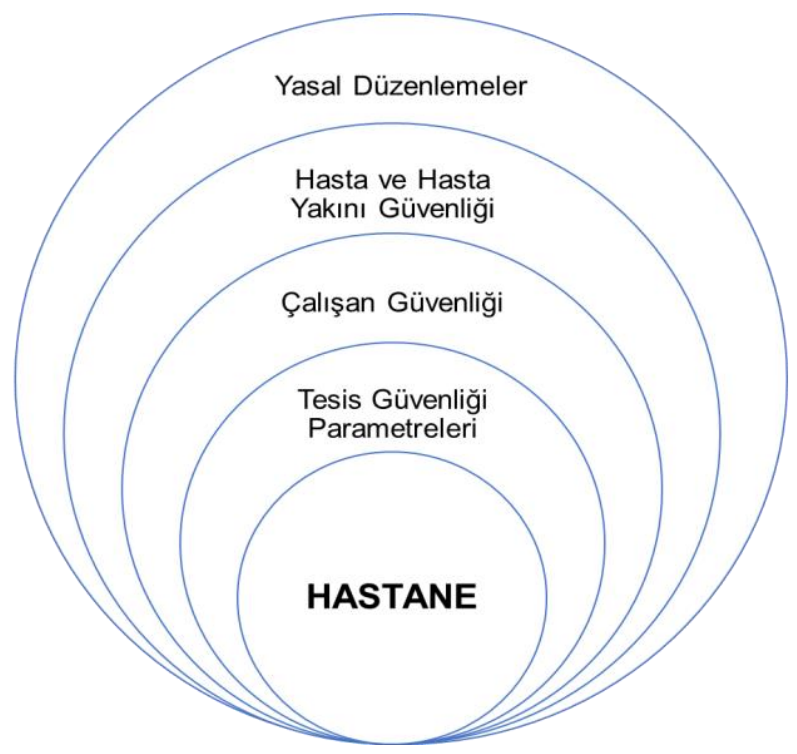

Şekil 1. Tesis Güvenliği Çerçevesi

Kaynak: Odacıŏlu, 2013:181

\section{Hastane Güvenlik Endeksi:}

Güvenlik endeksi olarak belirtilen ve algılanan bu yöntem sağlık alanında hazırlanan bir risk yönetim aracı ve kılavuzudur. Yöneticilere alınması gereken tedbirler hakkında daha önceden bilgi ve fikirler verir. Verdiği bu fikirler sayesinde daha kaliteli bir hizmet ve daha huzurlu bir sağlık tesisi ve işletmesi kurmak hayal olmaktan çıkar, bu ise sağlık yöneticisinin ufkunu açar. 
Hastane Güvenlik Endeksinin belirlenmesi, sağlık sektöründe risk yönetimi için yeni bir yoldur. Bu sağlık tesisinin güvenlik seviyesinin zamanla takip edilmesine de imkân sağlamaktadır. Hastaneler yüksek, orta veya düşük güvenlik seviyesinde sınıflandırılmaktadır.

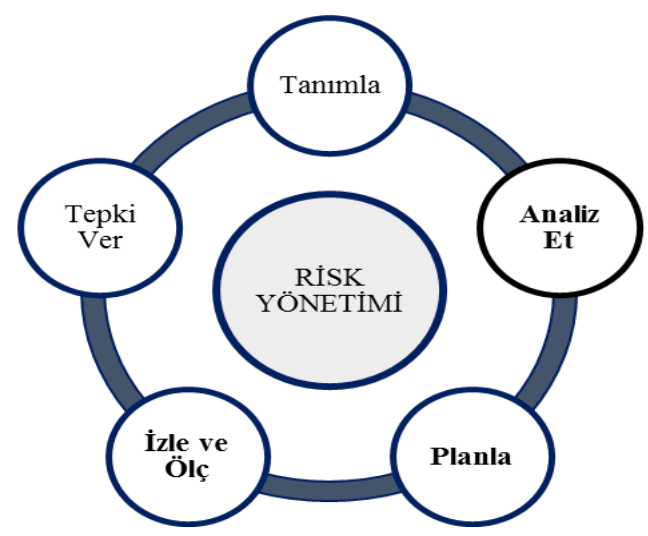

Şekil 2. Risk Yönetimi

Kaynak: ISO 90012015 Standardına Göre Risk Yönetimi

Hastane Güvenlik Endeksinin gelişimi başlangıçta Pan Amerikan Sağlık Örgütü Afet Azaltma Danışma Grubu (DiMAG) tarafindan iki yıllık bir süre içinde diyalog, test ve revizyon ile yürütülmüş ve sonra Latin Amerika ve Karayipler'deki diğer uzmanların da katkısı ile uzun bir sürecin sonunda şekillenmiştir. Hastane Güvenlik Endeksinin belirlenmesi, sağlık sektöründe risk yönetimi için bir yoldur. Hastane Güvenlik Endeksi çeşitli hastanelerde uygulanmaktadır (Özmen ve ark., 2013:14).

Sağlık Çalışanlarında Risk Değerlendirmesi 5 adımda yapılabilir:

- Tehlikelerin tanımlanması ve belirlenmesi,

- Risklerin ortaya konması ve değerlendirilmesi,

- Önlemlerin belirlenmesi ve sıralamaya konması,

- Önlemlerin uygulanması ve tatbik edilmesi,

- İzleme, gözden geçirme ve genel değerlendirme yapılması,

Göstergede yer alan maddeler neticesinde bir kılavuz ortaya çıkmıştır. Kılavuz güvenli hastaneler için elbette tek kaynak değildir, bu; hastane ve sağlik tesislerinin güvenliğini sağlamada sonraki yapılanmalar için bir rehberdir (Özmen, vd, 2013);

- Kategori A: Düşük risk kategorisindedir. Muhtemel felaket durumlarında hastane çalışmaya devam edecektir (Puan: 1-0,66).

- Kategori B: Orta derecede risk mevcuttur. Ekipman ve kritik hizmetler risk altındadır (Puan: $0,65-0,36)$.

- Kategori C: Ciddi risk altındadır. Sağlık çalışanlarının da hastalarında güvenliği tehlikededir. Acil tedbir alınması gerekmektedir (Puan: 0,35-0). 
Hastane Güvenlik Endeksini hesaplamada mühendisler ve sağlık profesyonelleri birlikte çalışır. Hesaplamada bahsedilen yapısal, yapısal olmayan ve fonksiyonel unsurlar değerlendirilir. Hızlı, güvenilir ve düşük maliyetli tanı aracıdır. Nispeten ucuz ve uygulanması kolay olduğundan, emniyet tedbirlerinin iyileştirilmesi konusunda ülkenin yatırımlarına öncelik verilmesinde önemli bir adımdır.

Tablo 3. Güvenlik Endeksi Kategorileri

\begin{tabular}{|c|c|l|}
\hline GÜVENLİK ENDEKSİ & KATEGORI TIPİ & NE YAPMALI? \\
\hline $0.66-1.00$ & Kategori A & Geniş zamanda önleyici tedbirler alınmalıdır. \\
\hline $0.36-0.66$ & Kategori B & Kısa vadede tedbir almak gerekir. \\
\hline $0.00-0.35$ & Kategori C & $\begin{array}{l}\text { Hastane personeli ve hastalar ciddi risk altındadır. } \\
\text { Acil tedbir almak gereklidir. }\end{array}$ \\
\hline
\end{tabular}

Kaynak: Özmen ve ark., 2013:14

\section{Tesis Yönetimi ve Güvenlik}

Hastane yönetimince, tesis güvenliği ile ilgili aksaklıkların tespiti ve konunun yerinde denetiminin sağlanması hastane bina turlarının yapılması ile mümkün olmaktadır. SHKS gereğince sağlık kurum ve kuruluşlarında Tesis Güvenliği Komitesinin kurulması zorunlu hale getirilmiştir. Tesis güvenliği komitesi düzenli aralıklarla toplanmalı, bina turlarında olası riskler belirlenmeli ve gerektiğinde düzeltici-önleyici faaliyetleri başlatmalıdır.

Bina turlarının nasıl yapılacağına dair düzenleme bulunmalıdır. Genel olarak turların kapsamı, periyotları, planları, sorumluları, kayıtlarının nasıl tutulacağ1 ve düzeltici-önleyici faaliyetlerin kimler tarafından yapılacağı, ana bina, varsa bağlı ek bina ya da binaları da göz önünde bulundurularak belirlenmiş olmalıdır. Bunlar kayıt alıına da alınmalıdır.

Tesis Yönetimi Planlaması aşağıdaki konuları içermektedir.

1. Yangın Güvenliği Sağlanması

2. Tehlikeli Maddelerin Yönetimi

3. Acil Durum Yönetimi

4. Tıbbi Ekipmanların Yönetimi

5. Emniyetin Sağlanması ve Güvenlik Hizmetleri

6. Destek Sistemlerin Sağlanması

7. Eğitim

Bina turlarını yapacak olan komisyon üyeleri ve ekipler aşağıdaki üyelerden teşekkül ettirilmelidir.

- Hastane Başhekimi veya yardımcısı, 
- İdari ve mali işler müdürü veya yardımcısı,

- Hasta bakım hizmetleri müdürü veya yardımcısı,

- Destek ve Kalite Hizmetleri Müdürü veya yardımcısı,

- Halkla İlişkiler ve Basın Birimi

- Hastane Başteknisyeni veya varsa hastane mühendisi,

- Afet ve Acil Durum Yönetimi Sorumlusu,

- Trbbi Cihaz Sorumlusu,

- Hastane güvenlik amiri,

- İlgili birim veya klinik temsilcisi,

A. Bu komitenin sekretaryası Destek ve Kalite Hizmetleri Müdürü veya yardımcısı tarafindan yürütülmelidir. Hastanenin büyüklüğü, kalite hedefleri ve birim dağılımına göre hastane yöneticisi tarafından uygun görülen elemanlar ekibe dâhil edilmelidir.

B. Bina turları sonucunda tespit edilen sorunların (bakım, onarım, işleyiş ile ilgili aksaklıklar vb.) giderilmesi amacıyla bir faaliyet planı yapılmalıdır.

C. Hastane kampüsü içinde gerekli oturma alanları tanzim edilmelidir.

D. Araç trafiği (park, geliş-gidiş vb.) için gerekli düzenleme yapılmalıdır.

E. Hastanenin tesis güvenliğine ilişkin düzenlemeler yazılı ve uygulanabilir olmalıdır.

F. Hastane temizlik kontrol komitesi tarafindan belirlenen çevre temizliğine yönelik yazılı bir düzenleme bulunmalı ve bunlar aralıklarla kontrol edilmeli ve kayıt altına alınarak takip edilmelidir.

G. Acil durum, afet planı ve güvenlik ile ilgili gerekli düzenlemeler yapılmalıdır.

Hastanelerde Tesis Güvenliğinin hastane içindeki tüm çalışma birimleri ile ilişkisi, irtibatı ve ortak çalışma konuları bulunmaktadır.

Kahramanmaraş Sütçü İmam Üniversitesi Sağlık Uygulama ve Araştırma Hastanesi (2017), Tesis Güvenliği Komitesinin Görev, Yetki ve Sorumluluklarını şöyle sıralamaktadır:

- Hastane alt yapı güvenliğini sağlamak,

- Kurumda can ve mal güvenliğini sağlanmak,

- Acil durum ve afet yönetimi çalışmalarını yapmak,

- Atık yönetimi çalışmalarını yürütmek,

- Tıbbi cihazların bakım, onarım, ölçme, ayar ve kalibrasyon planlarını ve kalibrasyonlarının yapılmasını sağlamak,

- Tehlikeli maddelerin güvenli yönetimini sağlamak,

- Hastane çevresinin düzenli ve temiz olmasını sağlamak,

- Asansör, elektrik, jeneratör, medikal gaz, atık su, havalandırma sistemlerinin denetim ve bakımını yaptırmak, 
- Yangın ve sabotajlara karşı gerekli tedbirleri almak, yılda en az bir defa yangın söndürme tatbikatı yapmak,

- Bina turlarından elde edilen verilerin değerlendirmesini yapmak,

- Gerektiğinde düzeltici-önleyici faaliyet başlatmak ve takibini yapıp sonuçlandırmaktır.

\section{Tesis Güvenliği Komitesi Çalışma Esasları:}

1. Tesis Güvenliğini sağlamaya yönelik çalışmalar, Sağlık Bakanlığı tarafından tesis güvenliği konularında yayınlanan mevzuatlara göre yapılır.

2. Komite; teknolojik, bilimsel ve insan kaynakları açısından sürekli gelişen sağlık hizmet alanlarının güvenliği konusunu sürekli gözden geçirerek ve iyileştirmelerin yapılmasını sağlar.

3. Tesis Güvenliği Komitesi HKS çerçevesinde tesis güvenliği kaynaklı; Hasta ve çalışanların can ve mal güvenliğini sağlamaya yönelik düzenlemeleri, çevre düzenlemesi, tesis kaynaklı düşmeleri engellemek için alınacak önlemler, hastanede su, elektrik enerjisi ve medikal gaz hizmetleri kesintisiz olarak verilmesinin sağlanması, asansörlerin güvenli kullanımına yönelik düzenlemeler, havalandırma sisteminin kontrolü ve bakımına yönelik düzenlemeler, elektrik sistemlerinin güvenli kullanımına yönelik düzenlemeler, Su depolarının güvenli kullanımına yönelik düzenlemeler, Medikal gaz sistemlerine yönelik düzenlemeler, Sıkıştırılmış gaz konteynırlarına yönelik düzenlemeler konularında çalışmalar yapar.

4. Tesis güvenliği komitesi altında kurulan tıbbi cihaz yönetiminden sorumlu ekip tarafından Tıbbi cihazların bölüm bazında envanteri, Tıbbi cihazların bakım, onarım, ölçme, ayar ve kalibrasyonlarına yönelik planlar hazırlanır.

5. Plan dâhilinde cihazların ölçme, ayar ve kalibrasyonları yapılması ve gerekli kayıtların düzenlenmesi sağlanır.

6. Tesis Güvenliği Komitesi 3 ayda bir toplanır, tesis güvenliği ile ilgili tüm verileri (olay bildirimleri, istatistiki çalışmalar vb.) gözden geçirerek gerekli düzeltici önleyici faaliyetleri başlatır, alınan kararlar karar defterine yazılarak kayıt altına alınır.

7. Komiteye KYB tarafından Güvenlik Raporlama Olay Bildirim ve Olay Bildirimi gönderildiğinde; konunun aciliyetine göre en kısa sürede, acil olmayan Olay Bildirimlerinde ise her ayın sonunda toplanılır.

8. Komite Olay Bildirimi ile ilgili kök neden analizi yaparak gerekli düzeltici önleyici faaliyetleri başlatır.

9. Olay bildirimine ilişkin analiz sonuçları ve yapılan faaliyetler Kalite Yönetim Birimine gönderir.

10. Komite başlattığı düzeltici önleyici faaliyetleri Güvenlik Raporlama Sistemi, Eğitim ve DÖF İzlem Formuna (Düzeltici ve Önleyici Faaliyetler) kaydederek izler.

11. Tesis güvenliğini ilgilendiren konularla ilgili çalışanların eğitim almasını sağlar. 


\section{Yangın Önleme ve Yangın Söndürme}

Sağlık Bakanlığınca, 26 Temmuz 2002 tarih ve 24827 sayılı Resmî Gazetede yayımlanan 2002/4390 sayılı "Binaların Yangından Korunması Hakkında Yönetmelik" maddesine göre hazırlanan ve 2008 yılında yayınlanan "Hastanelerde Yangın Önleme ve Söndürme Esasları Yönergesi” "nde gerekli önlemler ve tedbirler belirlenmiştir. Hastanelerde yangın güvenliği ile ilgili olarak iki konunun açıklığa kavuşturulması gereklidir;

- Hastanenin yangın güvenliği durumu saptanması,

- Yangın Güvenliği Emniyet Planı hazırlanması ve bu planlar aşă̆ıdaki konuları içermelidir.

* Yangına karşı koruyucu önlemleri, erken görme ve erken bastırma, hafifletme ve tesisten emniyetli kaçışı,

* Yangın önleme ve emniyet sistemlerini ve malzemelerini denetleme, test ve bakım sıklığı,

* Yangın ve duman durumunda tesisin emniyetli olarak hangi bölgelere boşaltılması,

Acil durumlarda müdahale ekibinin, söndürme, kurtarma, koruma ve ilk yardım ekipleri belirlenmeli, ilgili personele bu konularda gerekli eğitimler verilmeli ve yazılı görev bildirimleri de yapilmalidir.

- Hastaları tahliye edecek personelin bu konuda gerekli eğitimlerini almış olması gereklidir.

- Yılda en az iki defa olmak üzere yaz ve kış yangın simülasyonlarının gerçekleştirilmesi ve bu sürecin yazılı olarak raporlanması ve görülen aksaklıkların çözümüne yönelik faaliyetlerin yapilmas1,

- Hastane büyüklügüne ve hasta kapasitesine göre tesis yangın açısından düzenli olarak denetlenmeli ve gerekli önlemler alınmalıdır.

* Yangın çıkışlarının önleri kapanmamalıdır. Yangın çıkış levhaları hastane içinde uygun yerlere ve bütün insanlar tarafindan görülebilecek şekilde yerleştirilmelidir. Yangın çıkış levhaları gece veya elektrik kesildiğinde de görülebilecek özellikte olmalıdır.

* Yangın söndürme ekipmanlarına ulaşımın engellenmemelidir. Yangın çıkışları ve yangın tüplerini gösteren kat planları kendi katında bulundurulmalıdır.

- Yangın söndürücüler uygun yerlerde ve uygun sayıda olmalıdır ve mutlaka sabitlenmelidir ve kullanıma hazır olması için düzenli kontrol edilmelidir. (Söndürme tüpleri altı ayda bir kontrol edilmeli, yıllık genel bakımları yapılmalıdır). Otoparklarda, depolarda, tesisat dairelerinde ve benzeri yerlerde ayrıca tekerlekli tip söndürme tüpü bulundurulmalıdır.

* Elektrik kabloları açıkta olmamalı ve düzenli bir şekilde toplanmış olarak bulunmalıdır.

* Hastane, yangın erken uyarı sistemleri düzenli olarak test edilip sonuçları kayıt altına almalıdır. 
Hastanenin yangın güvenliği, Hastane Yangın Güvenliği Prosedürü ve ilgili talimatlarına göre, görevli yangın ekipleri, güvenlik ve çağrı merkezi ve tüm hastane çalışanlarının katılımı ile sağlanmalıdır.

\section{Tehlikeli Maddelerin Yönetimi}

14 Mart 1991 tarih ve 20814 sayılı Resmî Gazete 'de yayınlanan "Katı Atıkların Kontrolü Yönetmeliği”"nde tehlikeli atık kavramı, "Zararlı ve tehlikeli atık” başlığı altında şu şekilde tanımlanmıştır:

"Patlayıcı, parlayıcı, kendiliğinden yanmaya müsait, suyla temas halinde parlayıcı gazlar çıkaran, oksitleyici, organik peroksit2 içerikli, zehirli, korozif, hava ve su ile temasında toksik gaz bırakan, toksik ve ekotoksik özellik taşıyan ve Müsteşarlıkça tehlikeli ve zararlı atık olduğu onaylanan atıklardır “. Buna paralel olarak Resmî Gazetenin 14.03.2005 tarih ve 25755 sayılı nüshasında yayınlanan "Tehlikeli Atıkların Kontrolü Yönetmeliği”" "ne göre nasıl bertaraf edilmesi şartları belirlenmiştir. Tehlikeli atık bertaraf ve geri kazanım tesisleri için çevre lisansı alınması işlemlerinin de "Çevre Kanunu, (5491 sayıl1)" uyarınca yapılması gerekmektedir. Ayrıca Resmî Gazetenin 21.11.2008 ve 27061 sayılı nüshasında yayınlanan «Çevre Denetimi Yönetmeliği» tehlikeli atıkların bertaraf edilmesine açıklık getirmiştir. Atıkların yakılarak yok edilmesi konusu Resmî Gazetenin 06.10.2010 tarih ve 27721 sayılı nüshasında yayınlanan "Atıkların Yakılmasına İlişkin Yönetmelik” 'te düzenlenmiştir.

Atıkların tehlikeli olarak belirlenmesinde kullanılan listeler;

a) Maddelerin atılma nedenlerine göre,

b) Atılma işlemlerine göre,

c) Tehlikeli atıkların kökenlerine göre,

d) Tehlikeli atık olmasına neden olan bileşenlerine göre,

e) Tehlikeli özellikler listesine göre,

f) Atık yaratan faaliyetlere göre hazırlanabilmektedir.

Resmî Gazetenin 02.04.2015 tarih ve 29314 sayılı nüshasında yayınlanan «Atık Yönetimi Yönetmeliği» göre bir atığın tehlikeli atık olarak değerlendirilebilmesi için atığın sahip olması gereken bazı karakteristikler şunlardır:

* Yanıcı ve tutuşabilir olmak,

* Kendi kendine tepkimeye girmek,

* Patlayıcı olmak,

* Çürütücü ve paslandırıcı olmak,

* Radyoaktif özellikler göstermek,

* Bulaşıcı olmak, 
- Tahriş edici olmak,

* Hassas olmak,

Hastane Yönetimi, tehlikeli maddelerin kullanımı, kontrolü, depolanması, taşınması ve envanterinin tutulması, tehlikeli malzeme ve atıkların uzaklaştırılması için bir plan oluşturmalıdır.

- Hastanede tehlikeli madde kapsamında olan maddeler sınıflandırılmalı ve listelenmelidir.

- Kullanım alanlarında risk teşkil etmeyecek miktarlar belirlenmeli ve bu miktarlar bulundurulmalidir.

- $\mathrm{Bu}$ maddeler hastaneye geldiği ilk günden itibaren mutlaka etiketlenmeli ve kayıt altına alınmalıdır.

- Birbirleriyle etkileşimde bulunabilecek olan maddeler ayrı ayrı alanlarda depolanmalı ve bulundurulmalidir.

- Kullanıci personele, kullanım sırasında dikkat edilmesi gereken konularla ilgili olarak daha önceden gerekli eğitimler verilmelidir.

- Personel bu maddelere maruz kaldığında neler yapması ve nelerin yapılması gerektiği hakkında bilgilendirilmesi sağlanmalıdır.

Hastanede mevcut olan tehlikeli madde ve atıkların kontrolünün sağlanması, hastanede bulunan tehlikeli maddelerin (kimyasallar, kemoterapötik ajanlar, radyoaktif malzeme ve atıklar, zararlı gaz ve buharları) kullanımı, kontrolü, depolanması, taşınması, imhasına yönelik süreçleri içeren bir Atık Yönetim planın oluşturulmasının sağlanmasıdır. Ayrıca tehlikeli atıkların ayrı bölmelerde depolanmas1, Resmî Gazetenin 26.04.2011 tarih ve 27916 sayılı nüshasında yayınlanan "Atık Ara Depolama Tesisleri Tebliğı” uyarınca gerekli işlemler yapılmalıdır. Tehlikeli atık miktarındaki azalma, beraberinde bazı proses değişikliklerini de getirecektir (DPT, 2000)

- Üretimdeki girdilerde tehlikesiz ya da daha az tehlikeli malzeme seçimi,

- Üretim prosesinde teknoloji değişikliklerinin uygulanması,

- Atık azaltıcı yönetim sistemlerinin uygulanmasının etkinleştirilmesi,

- Alternatif ürün üretimine geçiş.

Tehlikeli atıklar için yapılabilecekleri şöyle sıralayabiliriz;

- Kullanılan/yeni alınan ekipmanın çalışan güvenliği açısından değerlendirilmelidir.

- Atık üreten cihazlara ait "Malzeme Güvenlik Bilgi Formları" yani MSDS (Material Safety Data Sheet) raporları kontrol edilerek atık içeriği ve tehlike oranları tespit edilmelidir. Ürün Güvenlik Bilgi Formları kurum içinde kimyasal malzemenin kullanıldığı yerlerde, acil serviste ve kurum hekimliğinde de bulundurulmalıdır.

- Tehlikeli madde yönetimi prosedürü hazırlanmalı ve uygulamaya konmalıdır. 
- Riskli alanlarda çalışanlarına özel periyodik tarama metotları geliştirilmeli, devamlı takip ve kontrol edilmelidir.

- Tehlikeli atıklar için ayrı bir geçici depo hazırlanmalı ve mavi atık bidonları olmalı ve bunların üzerinde atığın toplamaya başlandığı tarih yazılmalıdır.

- Atıklar katı, sıvı, gaz özelliklerine ve türlerine göre ayrı varillerde biriktirilmelidir.

- Atıklar toplanmaya başladığı tarihten itibaren 180 gün dolmadan atık deposuna gönderilmelidir.

- Atık varilleri 2/3 oranında doldurulmalı, kelepçeleri kapalı tutulmalıdır.

- Tehlikeli atıklar ünite içerisinde eldiven, maske ve koruyucu giysili personel tarafindan alınarak geçici atık merkezine getirilir.

\section{Radyoaktif Atıklar}

Radyoaktif atıklar, her türlü radyoaktif maddenin değişik alanlarda kullanılması sonucu meydana gelmektedir. Nükleer reaktör işlemlerinden ya da tıpta araştırma, askeri ve sınai etkinlikler gibi kaynaklardan üretilen atıklardır. Resmî Gazetenin 02.09.2004 tarih ve 25571 sayılı nüshasında yayınlanan "Radyoaktif Madde Kullanımından Oluşan Atıklara İlişkin Yönetmelik" te gerekli düzenlemeler yapılmıştır.

$\mathrm{Bu}$ atıkları diğer toksik endüstriyel atıklardan ayıran en belirgin özellik radyoaktif olmalarıdır. Radyoaktif maddeler tıp, endüstri, tarım alanlarında kullanıldığı gibi, büyük ölçüde 1sı ve elektrik enerjisi üretiminde de kullanılmaktadır. Türkiye'de üretilen radyoaktif atıkların ana kaynakları şunlardır:

- Nükleer araştırma reaktörleri,

- Özel tıp laboratuvar ve merkezleri,

- Hastaneler,

- Üniversite ve diğer araştırma laboratuvarları,

- Endüstriyel izotop kullanan kuruluşlar,

Ülkemizdeki radyoaktif atıkların güvenli bir şekilde işlenmesi, taşınması, geçici veya sürekli olarak depolanması için gereken önlemleri almak veya aldırmak görevi 2690 sayılı yasa ile Türkiye Atom Enerjisi Kurumu'na verilmiştir.

Hastanelerde radyasyon kaynağı bulunan üniteler; Radyoloji ünitesi, Anjiyo, Skopi, Endoskopi birimleri ve hasta yatak başı çekimleridir. Bunun için;

- Radyasyon Korunmasında Temel Güvenlik Standartları uygulanmalıdır.

- Dozimetre takipleri (2 ay) muntazam ve zamanında yapılmalıdır.

- Hemogram takibi (1 yıl) devamlı olmalıdır. 
- Periferik yayma (şüpheli sonuçlarda) zamanında yapılmalıdır.

- Gereksiz çekimler önlenmeli, hatalı çekim tekrarları tespit edilmeli ve önlenmesi için gerekenler yapılmalıdır.

- Radyasyon Güvenliği el kitabı hazırlanmalı, Radyasyon Güvenliği Komitesi kanalıyla tüm çalışanlar, ilgisi ve irtibatı olanlar bu konularda aydınlatılmalı ve eğitilmelidir.

Hastanelerden ve laboratuvarlardan çıkan katı radyoaktif atıklar, radyoaktif biriktirme kabı üzerinde Resmî Gazetenin 24.03.2000 tarih ve 23999 sayılı nüshasında yayınlanan "Radyasyon Güvenliği Yönetmeliği” 'nde belirtilen "Uluslararası Radyoaktif Atıklar Amblemi” bulunur ve kullanılan radyoaktif maddenin yaydığı radyasyonun tipine ve enerjisine göre uygun malzeme ile zırhlanır. Bu atık kaplarının içine yerleştirilen tıbbi atık torbaları dolduğunda ağızları sıkıca bağlanıp etiketlenerek uzun süreli radyoaktif atık bekletme deposunda aktivite değerleri belirlenen sınırların altına düşene kadar ( $<1$ mikro Sv/saat) tutulur. Beklemiş ve gerekli radyasyon ölçümleri yapılmış katı atıklar tıbbi atık olarak değerlendirilir. Radyoaktif olmayan atıklar, tehlikeli kimyasal maddeler radyoaktif atık biriktirme kabına atılmazlar.

\section{Tıbbi Atık Yönetimi}

Tıbbi Atıklar, Genel bir terim olup; canlılara yönelik aşılama, tedavi, araştırma ve teşhis yöntemlerinde kullanılan tüm katı, sıvı, yarı sıvı veya gaz halindeki maddeleri içerir. "Dünya Sağlık Örgütü Atık Yönetimi Komitesi” tıbbi atıkları sekiz grupta toplamaktadır (Candar, 2003).
a) Genel atıklar,
b) Patolojik atıklar
c) Radyoaktif atıklar
d) Kesici ve delici aletler
e) Kimyasal atıklar
f) Enfeksiyöz veya potansiyel olarak enfeksiyöz atıklar
g) Farmasötik atıklar
h) Basınçlı kaplar

Tıbbi atık yönetimi için gerekli düzenlemeler yapılmalıdır ve yazılı prosedürleri ve talimatlanı bulunmalıdır. Atıkların yönetimi ile ilgili yazılı bir düzenlemenin bulunması, bu düzenleme ile ilgili olarak; hastanenin tıbbi atıklarının toplanılmadan önce depolanması için geçici depolama ünitesi, Resmî Gazetenin 22.07.2005 tarih ve 25883 sayılı nüshasında yayınlanan "Tıbbi Atıkların Kontrolü Yönetmeliği” hükümlerine uygun olarak, mevzuatın öngördüğ̈̈ şartları taşıyan tıbbi atık deposu kurulmalıdır. Atıklardan kaynaklı enfeksiyöz ajanların bulaşmasının engellenmesi; atıkların kaynağında azaltılması atıkların kaynağında ayrıştırılması, tıbbi atık taşıma araçlarının temizliği ve bakımının sağlanması, taşıyıcıların bağışıklığının sağlanması ve düzenli sağlık kontrollerinin yapilmasidir. 
Resmî Gazetenin 26.03.2010 tarih ve 27533 sayılı nüshasında yayınlanan "Atıkların Düzenli Depolanmasına Dair Yönetmelik” uyarınca özellikle tıbbi atıklarla ilgili olarak çalışan tüm sağlık personelinde farkındalık oluşturulması için düzenli aralıklarla eğitim verilerek tıbbi atıkların şartlara uygun atık kovalarına atılması sağlanmalıdır. "Atık Yönetimi Genel Esaslarına İlişkin Yönetmelik” R.G. 05.07.2008/26927) hükümlerine göre atıkların toplanması ve taşınması ile ilgili talimatlar oluşturulmalı, tıbbi atık taşıma için ayrılan personel başka işlerde çalıştırılmamalı, ünite içerisinde taşıma az trafiğin olduğu yerlerden ve zamanlarda taşıma yapılması gerekmektedir. Atık deposunun periyodik olarak temizliği dezenfektanlarla yapılmalı ve kayıtları tutulmalıdır.

2016 yıl sonu itibari ile faaliyette olan 1527 sağlık kuruluşuna anket uygulanmış ve bu sağlık kuruluşlarının tamamında tıbbi atıkların diğer atıklardan ayrı toplandığı tespit edilmiştir. Sağlık kuruluşlarında 81 bin ton tıbbi atık toplanmış, bunların \%67,2'si düzenli depolama tesislerinde, $\% 17,3$ 'ü belediye çöplüklerinde, $\% 15,5$ 'i ise yakma tesislerinde bertaraf edilmiştir. Tıbbi atığın \%24,1'inin İstanbul, \%9,3'ünün Ankara, \%6,7'sinin ise İzmir'deki sağlık kuruluşlarında toplandığı tespit edilmiş ve bu miktar tıbbi atığın \%40,1'i üç büyükşehirde oluştuğunu göstermektedir. (TÜiK, 2017)

\section{ACIL DURUM YÖNETIMI}

\section{Hastane Acil Durum Planları}

Hastaneler olası deprem, bulaşıcı hastalık salgınları, çok sayılı yaralanmalar veya toplu kazalar vb hastanenin günlük işleyişini değiştirecek boyutta gerçekleşebilecek olaylara hazırlıklı olmak zorundadır. Bu nedenle "Hastane acil durum planları" hazırlanmalıdır. Bu planda görevleri olan personelin sorumluluk ve yetkileri belirlenmelidir. Bu konuda açıklayıcı bilgiler bulunan ve AFAD tarafından yayınlanan "Sağlık Kuruluşları İçin Afet Acil Yardım Planlama Rehberi-2009”"dan faydalanmak mümkündür.

Boğaziçi Üniversitesi Kandilli Rasathanesi ve Deprem Araştırma Enstitüsü, Afete Hazırlık Eğitim Birimi tarafından hazırlanan (2004), «Hastanelerde Afet ve Acil Durum Eylem Planları (HAP) ve Tesis Güvenliği Sağlıkı Hastaneler İçin Afete Hazırlıklı Olma Kılavuzu» da göz önünde bulundurularak hastane afet planları hastane yönetimince hazırlanabilir.

Acil durumlarda kullanılacak alternatif alanların belirlenmelidir. Acil durum karşısında görevli yönetici ve personelin eğitimleri daha önceden sağlanmalıdır. Acil durum planı dokümanter edilmiş olarak belirlenen alanlarda bulundurulması sağlanmalıdır. Acil durum planları yılda en az bir defa tekrar elden geçirilmeli, test edilmeli ve raporlanmalıdır. Acil Durum ve Afet Planı içerisinde;

1. Tesis ve Alanların Yerleşim Planı,

2. Yangınlara Karşı Alınacak Önlemler ve Yangın Sonrası Uygulanacak Hareket Tarzı,

3. Doğalgaz Kaçağı ve Yangınına Karşı Alınacak Önlemler ve Hareket Tarzı, 
4. Elektrik Kaçağı ve Yangınına Karşı Alınacak Önlemler ve Hareket Tarzı,

5. Hırsızlık Eylemlerine Karşı Alınacak Önlemler ve Hareket Tarzı,

6. Deprem Ve Doğal Afetlerde Alınacak Önlemler ve Hareket Tarzı,

7. Sonrası Eylemcilerin Kaçış Yollarında Alınacak Önlemler ve ilgili Mercilere Verilecek Bilgiler

8. Toplu Eylemler Karsisinda Uygulanacak Hareket Tarzı

9. Salgın Hastalıklar Karsısında Uygulanacak Hareket Tarzı

10. İlgili Kurum, Kuruluş ve Genel Kollukla irtibat Kurma Usulleri

11. Toplanma Yerleri GİBİ GİZLİ BİLGILLER YER ALIR.

Acil durum ve afet planı şu konuları içermelidir:

Tablo 4. Acil Durum ve Afet Planı İçeriği I

\begin{tabular}{|l|}
\hline \multicolumn{2}{|l|}{ Yangın } \\
\hline Deprem \\
\hline Patlama \\
\hline $\begin{array}{l}\text { Doğalgaz } \\
\text { Sabotaj, bombalama, } \\
\text { Sel, heyelan, yıldırım düşmesi }\end{array}$ \\
\hline Savaş \\
\hline Sabotaj, terör (kimyasal silah, biyolojik silah, vb. \\
\hline Genel elektrik kesintisi \\
\hline Genel su kesintisi \\
\hline Salgın Hastalık
\end{tabular}

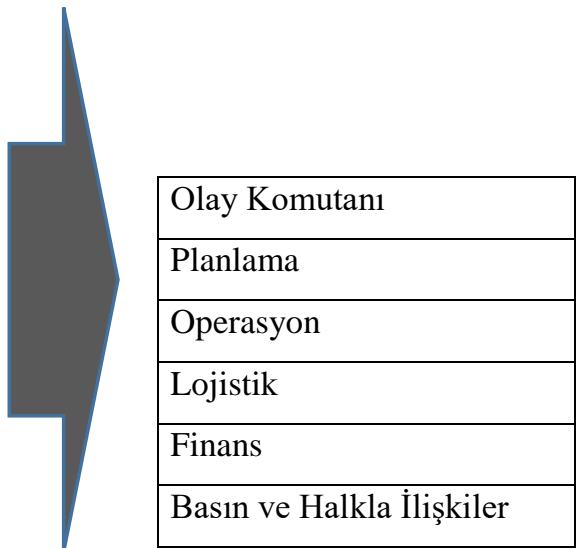

Başka bir şekilde ifade etmek istersek, şöyle bölümlendirmek mümkündür: 
Tablo 5. Acil Durum ve Afet Planı İçeriği II

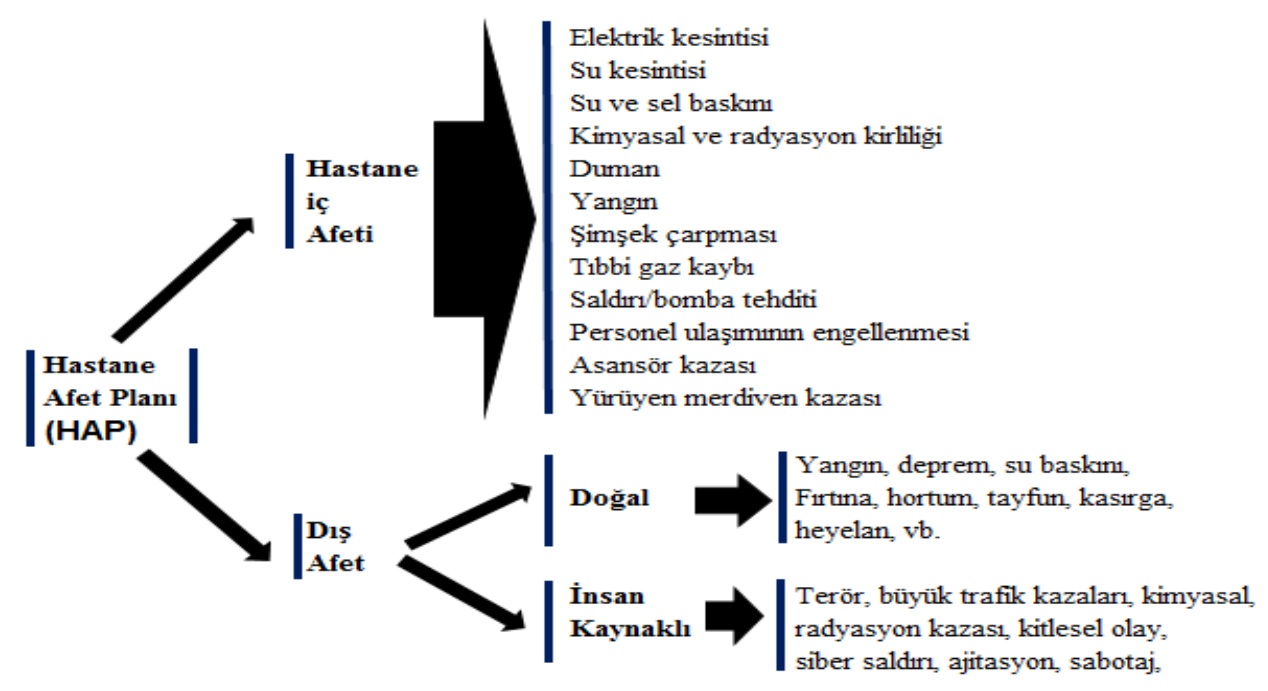

\section{Acil Durum ve Afet Planında Aşağıdaki Konular Açıklığa Kavuşturulmalıdır;}

- Acil Durum- Afet Görev Dağılımı ve Sorumlulukları

- İletişim-Haberleşmenin Sağlanma Yolları

- Basın ve Halkla İlişkilerin Sorumluları

- Tahliye Planı

- Yeni Yerleşim ve Çalışma Planı

- Lojistik Destek Sorumluları ve Görevleri (Sosyal Lojistik, Teknik Lojistik, İnsan Lojistiği, Destek Hizmetleri, Finans).

\section{TIBBİ CIHAZ YÖNETIMI}

Hastanede bulunan tüm tıbbi cihazların denetimi, testi ve bakımı için gerekli planlamalar yapılmalıdır. Cihazların kontrolü, testi ve bakım aralıkları önceden tespit edilip, belirlenmelidir. Belirlenen aralıklarla kontrolleri ve kalibrasyonları yapılarak yazılı kayıt altına alınmalıdır.

Hastane medikal gaz sistemlerinin denetimi ve bakımı düzenli olarak yapılmalıdır. Sıkıştırılmış gaz konteynırları sabitlenmiş olmalı ve periyodik kontrolleri yapılmalıdır. Hastane pnömatik sistemi çalışır vaziyette olmalı, bakım kayıtları muntazam tutulmalıdır. Aylık çalışma istatistikleri de devamlı takip edilmelidir.

\section{GÜVENLİK VE EMNIYET}

Hasta ve çalışanların can ve mal güvenliği sağlanmasına yönelik planlamalar yapılmış ve ortaya konmuş olmalıdır. Belirlenen riskli hasta grupları için ayrı planlar yapılmalıdır. Tesis güvenliği ve emniyetinde çalışan personelin yükümlülüklerinin belirlenmiş ve gerekli eğitime tutulmuş olmaları zorunludur. Hasta ve çalışanların güvenliği 7/24 saat sağlanmış olmalıdır. Genel olarak; Hastane özel 
güvenlik hizmetleri uygulama açısından en güç alanlardan biri olup, oldukça hassas bir konudur. Hastanede koruma ve güvenlik hizmetleri; koruma ve güvenlik görevlileri tarafından, Özel Güvenlik Hizmetlerine Dair Kanun (5188 sayıl1) ve bu Kanunun Uygulanmasına İlişkin Yönetmelik hükümlerine (R.G.07.10.2004/25606) göre yürütülür. Güvenlik amacıyla hasta kişi, hastasını hastaneye getiren hasta yakını, yatılı hastasını ziyarete gelen ziyaretçi, tüm hastane personeli hizmet verilen kişilerdir. Resmî Gazetenin 29.04.2009 tarih ve 27214 sayılı nüshasında yayınlanan "Sağlık Kurum Ve Kuruluşlarında Hasta Ve Çalışan Güvenliğinin Sağlanması Ve Korunmasına İlişkin Usul ve Esaslar Hakkında Tebliğ "'e göre planlama ve organizasyon yapılması gerekmektedir. Ayrıca Resmî Gazetenin 01.08.1998 tarih ve 23420 sayılı nüshasında yayınlanan "Hasta Hakları Yönetmeliğì" ne göre de hastanın güvenliğini hastane yönetimi sağlamakla görevlidir.

Tüm bu insanların psikolojik özellikleri, sağlık hizmetlerinin 24 saat süresince tam zamanlı bir şekilde devam etmesi, sağlık kurum ve kuruluşlarının halka açık yerler olması, adli olaylara sık rastlanılması özel olarak hastane güvenlik hizmetlerinin önemini artırmaktadır. Hastane güvenlik tedbirleri ve kuralları; Güvenlik personeline 5188 sayılı Özel Güvenlik Kanununa ve yönetmeliğine göre öğretilmelidir.

16 Ekim 2009 tarih ve 27378 sayılı Resmî Gazete de yayınlanan "Yataklı Sağlık Tesislerinde Acil Servis Hizmetlerinin Uygulama Usul ve Esasları Hakkında Tebliğ” adlı yazıda acil servislerde alınması gereken güvenlik önlemleri şu şekilde belirlenmiştir;

- Acil servislerde güvenlik, resmi kolluk kuvveti veya özel güvenlik personeli vasıtası ile ve yeterli sayıda güvenlik kamerası desteği ile sağlanır.

- Tibbi işlemlerin gerçekleştirildiği alanlar ile cerrahi müdahale, ameliyathane, yoğun bakım gibi kritik birimlere görevli personel dışında ilgisi olmayan kişilerin girmesi ilgilisine göre açılma özelliği olan kapılar konulmak suretiyle engellenir.

- Görevli personel, hasta, hasta yakını, ziyaretçi, ambulans, hasta nakil aracı veya sedye ile getirilen acil hastaların alındığı girişler gerekli idari ve teknik önlemler alınarak kontrol altında tutulur.

- Acil servisle bağlantılı otopark alanlarında da yeterli ışıklandırma, gözetleme kameraları ve güvenlik personeli ile gerekli güvenlik önlemleri alınır.

\section{DESTEK SISTEMLERİ YÖNETIMMI}

Hastaneler 7 gün 24 saat süre ile hizmet vermeleri esasında destek hizmetlerini (içme suyu, elektrik enerjisi vb.) planlamalı ve devamlı olarak kontrollerini gerçekleştirmelidir. Arızalanma veya acil durumlardaki karşılama kapasitelerini belirlemeli ve gerektiğinde nasıl temin edileceği önceden planlamış olmalıdır.

\section{Neler Yapılmalıdır?}


- Tesis Güvenliği ve Yönetimi ile ilgili olarak bu işleri takip ve kontrol edecek Tesis Güvenliği komisyonu kurulmalıdır. Mümkün ise bu yöneticinin "Hastanelerde Risk Yönetimi" konusunda bir eğitim almış olması da işleyiş takibi ve yönetimi açısından önemlidir.

- Yangın güvenliği açısından Hastanelerde mutlaka yılda en az iki defa Yangın Tatbikatı yapilmalıdir.

- Hastane Acil Durum planına göre yapılacak tatbikata göre hastanenin durumu gözden geçirilmelidir. Acil durumlarda hastane boşaltım planının uygulaması gerçekleştirilmelidir.

- Kalibrasyon gerektiren medikal cihazların tespiti ve kalibrasyonları zamanında yapılmalıdır.

- Yangin durumunda personelin görevleri, Hastane Acil Durumunda personelin görevleri, bu durumlarda neler yapmaları gerektiği konularında eğitimler daha önceden verilmelidir.

- Hastanede tesis bakım işlemleri ile ilgili gerekli düzenlemeler yapılmalıdır. Hastanenin tesis bakım planlarının oluşturulmasının ve asansörlerin, havalandırma sisteminin ve kazan dairelerinin denetimi ve bakımının düzenli olarak yapılmasının sağlanmasıdır.

- Hastane elektrik sistemlerinin denetimi ve bakımı düzenli olarak yapılmalı ve rapor edilmelidir. Elektrik sistemleri ile ilgili gerekli güvenlik önlemleri alınmış olmalıdır

- Elektrik şebekesi dışında hastanenin elektrik ihtiyacını karşılayacak jeneratör aktif ve bakımlı çalışır durumda bulunmalıdır. Jeneratör ruhsatları bulunmalıdır. Jeneratörlerin bakım ve onarım kayıtları mevcut olmalıdır

- Dışarıdan alınan destek hizmetler uygun şekilde denetlenmeli ve denetim kayıtları bulunmalidir.

- Hastanenin genel temizliği ile ilgili gerekli düzenlemeler yapılmalıdır. Hastanenin genel temizliğinden sorumlu bir temizlik komitesi belirlenmelidir.

a) Hastane yönetimi, hastanenin genel temizliğinden sorumlu bir temizlik komitesi belirlemelidir.

b) Komite belirlediği aralıklarla, hastanedeki tüm alanların temizliklerini düzenli olarak kontrol etmeli ve denetimleri kayıt altına almalıdır.

c) Temizlik prosedürü oluşturularak prosedüre uygun talimatlar hazırlanmalı ve bu talimatlara uyum gösterilmesi sağlanmalıdır.

d) Hastanelerde riskli alanların belirlenerek temizlik ve dezenfeksiyon işlemlerinin bu alanlara özgü yapılması sağlanmalıdır.

- Hastanenin güvenli ve kesintisiz su ihtiyacını karşılamak üzere gerekli düzenlemeler bulunmalidır.

a) Su kesintisi durumunda hizmetin aksamasının önlenmesi; düzenli su numune kontrolleri ile hasta ve personel güvenliğinin sağlanmasıdır.

b) Hastanenin su deposu olmalidır.

c) Su deposu galvanize ve paslanmaz çelikten olmalıdır. 
d) Su depolarının bakımı düzenli olarak yapılmalı ve kayıtları mevcut olmalıdır.

e) Su numune kontrolleri düzenli olarak yapılmalı ve kayıt altına alınmalıdır.

\section{EĞíTiM}

Hastanelerde yangın emniyet eğitimi gerek hastane personeline ve gerekse hastalara bir yangın anında neler yapacaklarını öğretmek için yapılmalıdır. Bu konuyla ilgili talimatlar hazırlanarak dağıtılmalı ve ilgi yerlere asılmalı ve bu konuda devamlı eğitim verilmelidir.

Hastanede bulunan yangın söndürme cihazının nasıl kullanılacağı bütün personele tatbikatlar yaptırılarak öğretilmelidir. Hastanelerde, hastanenin büyüklüğüne göre kurulacak söndürme, kurtarma, koruma ve ilk yardım ekipleri yetiştirilmesi için yapılacak tatbikatların nerde, kaç saat devam edeceği ve nasıl yapılacağı, varsa, sivil savunma uzmanınca, yoksa ekip başkanlarınca hazırlanıp hastane idarecisi tarafından kabul ve tasdik edilen bir programla yürütülmelidir (Ak ve ark., 1998: 329-346).

\section{SONUÇ}

Çağdaş ve modern bir toplum olmanın ana şartlarından biri afetlerde zarar görenlerin mağduriyetini gidermek, yaralarını kısa sarmak ve sosyal hayata tekrar kavuşmalarına yardımcı olmaktır.

Sağlık kuruluşlarına ve işletmelerine bu durumlarda büyük işler ve görevler düşmektedir. Yapısal unsurlar anlamında binaların proje olarak depremlere dayanıklı olarak inşası veya sonradan depreme dayanıklı hale getirilmesi afetlerde hastanelerde yaşanacak can ve mal kaybını engelleyecek ve azaltacaktır.

Büyük harcamalar gerektirmeyen yapısal olmayan unsurlar ise sağlık kuruluşları ve hastaneler için oldukça kritiktir. Bu konuda alınacak tedbirler, afetlerde hastanelerin işlev kaybını önleyecek ve daha düzgün hizmet vermesini temin edecektir. Özellikle salgın hastalık zamanında hastanelerimizde yapılacak çalışmalar ve hazırlıklar için el kitapçığı hazırlanmalı, personel de bilgilendirilmelidir.

Fonksiyonel unsurlar anlamında eğitim, uygulama ve tatbikatlar bizim her daim konuyla iç içe olmamızı sağlayıp eksiklerimizi göstererek tedbirler almamızı sağlayacaktır. Bu nedenle, Hastane Güvenlik Endeksi bu anlamda elimizde çok sağlam bir bilgi ve dokümandır. Her üç unsur yönünden Türkiye'deki hastanelerin denetlenmesi, kontrol edilmesi hastanelerin afetlere hazırlığı konusunda bize ciddi datalar sunacaktır. Afetlerde kesintisiz sağlık hizmeti sunabilmek için buna benzer ulusal politikalar belirlenmeli ve sektörler arası iş birliği mutlaka sağlanmalı ve koordine edilmelidir.

Sonuç olarak, doğal afetleri ve salgınları önlemek mümkün değildir ama alınacak tedbirlerle, yapılacak planlarla zararları azaltmak, azami düzeye indirmek ve hizmet kalitesini yükseltmek mümkündür. Bunun için ise hastane yöneticilerimizin bu konularda bilgili, hazırlıklı, deneyimli ve tedbirli olması gerekmektedir. 


\section{KAYNAKLAR}

Ak, B., Mete, M., ve Sargutan, E. (1998). Hastanelerde Ev İdaresi Hizmetleri. Selçuk Üniversitesi Basımevi, Konya

Atık Ara Depolama Tesisleri Tebliği (R.G. 26.04.2011 / 27916)

Atık Yönetimi Yönetmeliği (R.G. 02.04.2015 / 29314)

Atık Yönetimi Genel Esaslarına İlişkin Yönetmelik (R.G. 05.07.2008 / 26927)

Atıkların Düzenli Depolanmasına Dair Yönetmelik (R.G. 26.03.2010 / 27533)

Atıkların Yakılmasına İlişkin Yönetmelik (R.G. 06.10.2010 / 27721)

Binaların Yangından Korunması Hakkında Yönetmelik (R.G. 26.07.2002 / 24827)

Candar, G. (2003, Ekim). Atık Yönetimi Uygulamasında Adım Adım. 3. Sterilizasyon ve Dezenfeksiyon Kongresi, Muğla.

Çevre Kanunu'nda Değişiklik Yapılmasına Dair 5491 Sayılı Kanun (Kabul Tarihi: 26.04.2006),

Çevre Denetimi Yönetmeliği (R.G. 21.11.2008 / 27061)

Demircioğlu, M. (2010) Güvenli Hastanelerde Tasarım: Türkiye uygulaması, 2. Uluslararası Sağlıkta Performans ve Kalite Kongresi, Ekim 2010, Ankara.

Deprem Bölgelerinde Yapılacak Binalar Hakkındaki Yönetmelik (R.G. 06.03.2007 / 26454),

DPT (2000) VIII. Beş Yıllık Kalkınma Planı (2001-2005), İçme Suyu, Kanalizasyon, Arıtma Sistemleri ve Katı Atık Denetimi Özel İhtisas Komisyonu Raporu, Ankara.

Hasta Hakları Yönetmeliği (R.G. 01.08.1998 / 23420),

Hastane Hizmet Kalite Standartları (HKS, 2011), Tedavi Hizmetleri Genel Müdürlüğü Performans Yönetimi ve Kalite Geliştirme Daire Başkanlığı, Ankara.

Hastaneler İçin Akreditasyon Standartlar (JCI-2014), Joint Commission International, Türkçe, 5'inci Edisyon, ISBN 978-1-59940-837-8

Hastanelerde Afet ve Acil Durum Eylem Planları (HAP) ve Tesis Güvenliği Sağlıklı Hastaneler İçin Afete Hazırlıklı Olma Kılavuzu (2004) ISBN 975-6193-31-X Boğaziçi Üniversitesi Kandilli Rasathanesi ve Deprem Araştırma Enstitüsü, Afete Hazırlık Eğitim Birimi.

ISO 90012015 Standardına Göre Risk Yönetimi, https://www.isokalitebelgesi.com/iso-9001-2015standardi-risk-firsat-yonetimi-degerlendirme-analiz-yaklasim-nedir-nasildir-riskler-nasildegerlendirilir e. 20.02 .2020 
Hastanelerde Yangın Önleme ve Söndürme Esasları Yönergesi (2008), Sağlık Bakanlığı, Ankara, Kahramanmaraş Sütçü İmam Üniversitesi, Sağlık Uygulama ve Araştırma Hastanesi, Görev Tanımlar1 (Kod: KU.YD.147, $\quad$ Yayın Tarihi: 03.08.2017), http://hastane.ksu.edu.tr/depo/belgeler/KU.YD.147\%20TES\%C4\%B0S\%20G\%C3\%9CVENL\%C4\%B 0\%C4\%9E\%C4\%B0\%20KOM\%C4\%B0TES\%C4\%B0\%20G\%C3\%96REV\%20YETK\%C4\%B0\%20 VE\%20SORUMLULUKAR 1711091538174734.pdf e.15.02.2020)

Katı Atıkların Kontrolü Yönetmeliği (R.G.14.03.1991 / 20814)

Odacıŏlu, Y. (2013) Hastane Yönetimi “Tesis Güvenliği”. Nobel Kitabevi, Ankara

Özel Güvenlik Hizmetlerine Dair 5188 Sayılı Kanun (R.G. 26.06.2004 / 25504)

Özel Güvenlik Hizmetlerine Dair Kanunun Uygulanmasına İlişkin Yönetmelik (R.G. $07.10 .2004 / 25606)$

Özmen, P., Türk, Y. Z., ve Çetin, M., (2013). Afetlerde Güvenli Hastaneler, Gümüşhane Üniversitesi Sağlık Bilimleri Dergisi. 2(4): 547-561.

Radyasyon Güvenliği Yönetmeliği (R.G.: 24.03.2000 / 23999)

Radyoaktif Madde Kullanımından Oluşan Atıklara İlişkin Yönetmelik (R.G.: 02.09.2004 /25571)

Sağlık Bakanlığına Bağlı Sağlık Kurum ve Kuruluşlarında Kaliteyi Geliştirme ve Performans Değerlendirme Yönergesi, (Sağlık Bakanlığı, 23.03.2007 tarih ve 2542 sayılı makam onayı)

Sağlık Hizmeti Kalitesinin Geliştirilmesi ve Değerlendirilmesine Dair Yönetmelik (2013), (R.G.: 06.08.2013 / 28730), Sağlık Bakanlığ1

Sağlık Kuruluşları İçin Afet Acil Yardım Planlama Rehberi (2009), Afet ve Acil Durum Müdürlüğü, (AFAD) İstanbul

Sağlık Kurum ve Kuruluşlarında Hasta ve Çalışan Güvenliğinin Sağlanması ve Korunmasına İlişkin Usul ve Esaslar Hakkında Tebliğ (2009), (R.G.: 29.04.2009 /27214), Sağlık Bakanlığı

Sağlıkta Kalite Standartları (Hastane), (2016), ISBN: 978-975-590-558-7. Sağlık Bakanlığı

Sur, H. ve Çetin S, (2002) Hastanelerde güvenlik sorunu üstüne. Hospital News Hastane Dergisi, 3(15), 2002.

Şengöz, Burak, Güvenlik Endeksi ve Güvenli Hastaneler https://buraksengoz.wordpress.com/2016/04/21/2/ 20.02.2020

Tehlikeli Atıkların Kontrolü Yönetmeliği (R.G.:14.03.2005 / 25755)

Tıbbi Atıkların Kontrolü Yönetmeliği (R.G.: 22.07.2005 / 25883) 
TS 498 Türk Standardı ICS 91.040. (1997), Yapı Elemanlarının Boyutlandırılmasında Alınacak Yüklerin Hesap Değerleri, Türk Standartlar Enstitüsü

TS 500 Türk Standardı ICS 91.080.40. (2000), Betonarme Yapıların Tasarım ve Kuralları, Türk Standartlar Enstitüsü

TÜİK, Sağlık Kuruluşları 2016 Atık İstatistikleri, TÜİK Haber Bülteni, Kasım 2017, Sayı: 24871, Türkiye Atom Enerjisi Kurumunun Muafiyetleri Ve Bazı Düzenlemeler Yapılması Hakkında Kanun (2690 say1l1), (R. G. 13.07.1982 / 17753)

Yataklı Sağlık Tesislerinde Acil Servis Hizmetlerinin Uygulama Usul ve Esasları Hakkında Tebliğ (2009), (R.G.: 16.10.2009 / 27378), Sağlık Bakanlığ1 